Proc. Estonian Acad. Sci. Biol. Ecol., 2006, 55, 1, 51-60

\title{
Polychlorinated dibenzo-p-dioxins and dibenzofurans in Baltic herring and sprat in the north-eastern part of the Baltic Sea
}

\author{
Ott Roots $^{\mathrm{a}^{*}}$, Karl-Werner Schramm ${ }^{\mathrm{b}}$, Mart Simm$^{\mathrm{c}}$, Bernhard Henkelmann $^{\mathrm{b}}$, \\ and Ain Lankov ${ }^{\mathrm{c}}$ \\ a Estonian Environmental Research Centre Ltd., Marja 4D, 10617 Tallinn, Estonia \\ ${ }^{\mathrm{b}}$ GSF-National Research Center for Environment and Health, Institute of Ecological Chemistry, \\ Ingolstaedter landstr. 1, 85764 Neuherberg, Germany \\ ${ }^{c}$ Estonian Marine Institute, University of Tartu, Marja 4D, 10617 Tallinn, Estonia
}

Received 19 July 2004, in revised form 4 May 2005

\begin{abstract}
The concentrations of polychlorinated dibenzo-p-dioxins and dibenzofurans (PCDD/PCDF) were studied in two fish species, Baltic herring (Clupea harengus membras L.) and sprat (Sprattus sprattus balticus Schn.), in Estonian coastal waters and the open Baltic Sea in spring and autumn 2002. For analyses, 493 individual herring were combined to 20 pools and 246 individual sprat were combined to 8 pools. A positive correlation between the PCDD/PCDF concentration and age of herring (length, weight) both in spring and autumn was found to be statistically reliable. Bioaccumulation of PCDD/PCDF into the organism of fish from the studied waters depends on the age, length, and sex of the fish, and the fishing ground.
\end{abstract}

Key words: PCDD, PCDF, Baltic Sea, herring, sprat, Estonia.

\section{INTRODUCTION}

The Baltic Sea, as a virtually enclosed and fairly shallow sea, is particularly vulnerable to persistent organic pollutants (POPs). It takes tens of years for all the water in the closed system to be renewed. It is also a cold sea with a short reproductive season. In addition, the Baltic Sea is the final destination of discharges and land run-off from many highly industrialized countries. Fourteen countries lie within the catchment area of the Baltic Sea.

* Corresponding author, Ott.Roots@klab.ee 
Polychlorinated dibenzo- $p$-dioxins (PCDD) and polychlorinated dibenzofurans (PCDF) are a group of toxic and persistent chemicals, whose effect on human health and on the environment include dermal toxicity, immunotoxicity, reproductive effects and teratogenicity, endocrine disrupting effects and carcinogenicity. PCDD/PCDF have never been produced internationally and have never served any useful purpose. The term "dioxins" refers to 75 congeners of PCDD and 135 congeners of PCDF. Amongst these 210 congeners, 17 congeners can have chlorine atoms at least in the positions 2, 3, 7, and 8 of the parent molecule. These 17 2,3,7,8-substituted congeners are toxic to many laboratory animals, resistent towards chemical, biological, and physical attack, and thus may accumulate in the environment and in organisms, such as animals and humans (UNEP Chemicals, 1999).

From the point of view of human health the most interesting are the toxicant concentrations in the food, in the case of the sea, first and foremost in the fish. It is thought that the people living near the Baltic Sea receive $80-85 \%$ of the total toxicants from the fish and fish products (Koistinen et al., 1995; Kiviranta et al., 2003). Infants born to Swedish fishing families with a diet high in fish from the Baltic Sea appear to have a slightly lower birth weight than infants born to other Swedish families (Rylander et al., 1995).

We selected for our study Baltic herring (Clupea harengus membras L.) and sprat (Sprattus sprattus balticus Schn.) as the most important commercial fishes in Estonia. The aim of this study was to determine the concentrations of two compounds - PCDD and PCDF - in the organisms of the fish from different parts of the Estonian economic area of the Baltic Sea and the open Baltic Sea. These compounds are especially toxic, they are persistent in the nature and accumulate in the nature.

\section{MATERIALS AND METHODS}

\section{Fish sampling and sample preparation}

Baltic herring and Baltic sprat were caught with commercial trawlers along the Estonian coast. To determine the PCDD/PCDF content in the Baltic herring and sprat, samples were collected from three areas in Estonian coastal waters (western and central parts of the Gulf of Finland and the Gulf of Riga (only herring)) and the open Baltic Sea in March and September 2002. The selected sampling areas were located in the main fishing grounds for Estonian herring and sprat fishery and the main spawning and nursery areas of these species near Estonian coasts (Raid, 1996).

All the fish were measured. Total weight and length were determined to the nearest $0.1 \mathrm{~g}$ and $1 \mathrm{~mm}$, respectively. Also the gender and the maturity of the gonads of the fish were determined. Otoliths were used for ageing the fish. The age was determined as the number of hyaline rings and the individual was moved to the next age group on 1 January. Pooling of fish was based on two determinants: length 
and catchment area. The pooled samples were sealed in glass containers and stored at $-20^{\circ} \mathrm{C}$ for subsequent analysis.

Fish sampling in spring 2002 and PCDD/PCDF analysis followed the recommendations of the HELCOM COMBINE Monitoring Programme from 1998. For analysis of fish muscle, the epidermis and subcutaneous tissue should be carefully removed from the fish. Samples should be taken under the red muscle layer. In order to ensure uniformity of samples, the right side dorso-lateral muscle should be taken as sample. For analysis, 304 individual herring were combined to 8 pools. The number of individual herring in pools varied from 17 to 66 .

In autumn 2002 the head, tail, and viscera were removed from the analysed fish so that the summarized dioxin level in all the parts of the fish used for human consumption could be determined. For analysis 189 individual herring were combined to 12 pools and 246 individual sprat were combined to 8 pools. The number of individual herring in pools varied from 9 to 20 and of individual sprat from 26 to 35 .

\section{Chemicals}

All solvents used as well as the silica, alumina, and florisil adsorbents were of trace analysis quality and purchased from LGC Promochem (Wesel, Germany). The $\mathrm{C}_{18}$-modified silica (Isolute C18) was purchased from Separtis GmbH (GrenzachWyhlen, Germany). The ${ }^{13} \mathrm{C}$-labelled standards were from Cambridge Isotope Laboratories (Andover, MA, USA) or Wellington Laboratories (Guelph, Ontario, Canada).

\section{Analysis of fat and organochlorines}

Each pool of the fish samples was freeze dried completely and homogenized. Of each pool $7.5 \mathrm{~g}$ was spiked with ${ }^{13} \mathrm{C}$-labelled PCDD/PCDF standards and extracted using pressurized liquid extraction (ASE 200, Dionex GmbH, Idstein, Germany) with $n$-hexane/acetone $75 / 25$ as the extraction solvent. The fat concentration in the extract was determined gravimetrically.

\section{Clean-up}

For the analysis of PCDD and PCDF the clean-up procedure shown in Fig. 1 was applied to the extracts. Fraction A and B of the alumina column in the PCDD/PCDF clean-up was used for the analysis of polychlorinated biphenyl (PCB). For that the solvents were reduced and changed to $0.2 \mathrm{~mL}$ acetonitrile, which was placed on a solid-phase extraction (SPE) cartridge filled with $1 \mathrm{~g} \mathrm{C}_{18}$-modified silica (conditioned with $6 \mathrm{~mL}$ acetonitrile) and rinsed first with two portions of $0.4 \mathrm{~mL}$ and finally with $3 \mathrm{~mL}$ of acetonitrile through the cartridge. All acetonitrile fractions were combined and reduced to a final volume of $10 \mu \mathrm{L}$ by a gentle stream of nitrogen. 


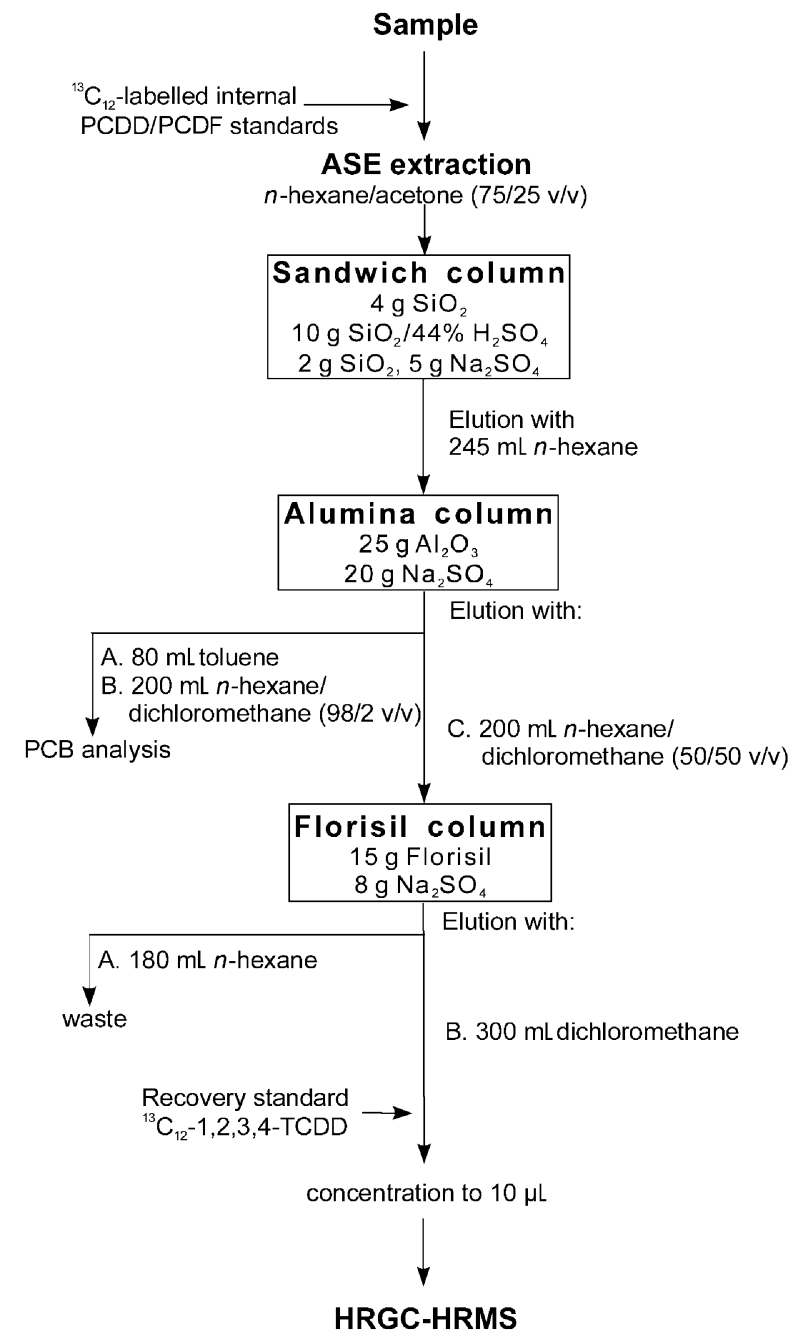

Fig. 1. The clean-up procedure.

\section{Instrumentation}

The PCDD/PCDF analysis was performed with a high resolution mass spectrometer Finnigan MAT 95S (Thermo Electron GmbH, Bremen, Germany) coupled with an Agilent GC 6890 (Agilent Technologies, Palo Alto, CA, USA). Chromatographic separation was achieved by splitless injection (cold injection system CIS4, Gerstel GmbH, Mülheim, Germany) of $1 \mu \mathrm{L}$ on a Restek Rtx-2330 column with a length of $60 \mathrm{~m}$, ID $0.25 \mathrm{~mm}$, ft $0.1 \mu \mathrm{m}$ (Restek GmbH, Sulzbach, Germany). The $\mathrm{GC}$ oven was programmed as follows: $90^{\circ} \mathrm{C}$ initial hold for $1.5 \mathrm{~min}$, increase at a rate of $30^{\circ} \mathrm{C} / \mathrm{min}$ to $200^{\circ} \mathrm{C}$ followed by an increase of $2^{\circ} \mathrm{C} / \mathrm{min}$ to $248^{\circ} \mathrm{C}$, then $20^{\circ} \mathrm{C} / \mathrm{min}$ to $260^{\circ} \mathrm{C}$, and a final hold at $260^{\circ} \mathrm{C}$ for $15 \mathrm{~min}$. The MS was operated 
in SIM mode at a resolution of 10000 , and the two most intense ions of the molecular ion cluster were monitored for the unlabelled and labelled isomers.

The PCB analysis was performed with a high resolution mass spectrometer Finnigan MAT 95 (Thermo Electron GmbH, Bremen, Germany) coupled with an Agilent GC 5890 Series II (Agilent Technologies, Palo Alto, CA, USA). Chromatographic separation was achieved by splitless injection (cold injection system CIS3, Gerstel GmbH, Mülheim, Germany) of $1 \mu \mathrm{L}$ on a J\&W DB-XLB column with a length of $60 \mathrm{~m}$, ID $0.25 \mathrm{~mm}$, ft $0.25 \mu \mathrm{m}$ (Agilent Technologies, Palo Alto, CA, USA). The GC oven was programmed as follows: $90^{\circ} \mathrm{C}$ initial hold for $1.5 \mathrm{~min}$, increase at a rate of $15^{\circ} \mathrm{C} / \mathrm{min}$ to $200^{\circ} \mathrm{C}$ followed by an increase of $3^{\circ} \mathrm{C} / \mathrm{min}$ to $235^{\circ} \mathrm{C}$, hold for $10 \mathrm{~min}$, then $8^{\circ} \mathrm{C} / \mathrm{min}$ to $320^{\circ} \mathrm{C}$, and a final hold at $320^{\circ} \mathrm{C}$ for $15 \mathrm{~min}$. The MS was operated in SIM mode at a resolution of 8000 , and the two most intense ions of the molecular ion cluster were monitored for the unlabelled and labelled isomers.

\section{RESULTS AND DISCUSSION}

Chemicals are nowadays produced and marketed in great numbers. So far, dangerous compounds have been found mainly as a result of chemical monitoring, carried out after the appearance of problems relating to human health. The concentrations of chloroorganic compounds (polychlorinated biphenyls, and chloroorganic pesticides, well-known DDT, lindane, etc.) in the biota of the Estonian coastal waters of the Baltic Sea have been studied since the middle of the 1970s (Roots, 1996). The differences in hydrological features and the lack of information about fish migrations can make the situation in the Baltic Sea more complicated than in fresh waters. Besides the age of the fish also other characteristics such as the length, sex, weight, fat content, maturity, etc., should be taken into account (Roots \& Aps, 1993). In Estonia dioxins have not been determined in fish before 2002.

Fish and fish products play a significant role in dietary intake of PCDD/PCDF. In Finland, the Baltic herring alone accounted for $52 \%$ of the total intake of PCDD/PCDF (Kiviranta et al., 2003). EU Council Regulation 2375/2001 put the threshold limit value of dioxins in fish at $4 \mathrm{pg} T E Q / \mathrm{g}$ fresh weight. However, the Russian Federation, for example, has an almost three times higher threshold limit value of dioxins in fish products $-11 \mathrm{pg}$ TEQ/g fresh weight or $88 \mathrm{pg} / \mathrm{g}$ fat (Shelepchikov et al., 2003). The EU Council Regulation mentions the Baltic Sea fish separately because their dioxin concentrations presumably exceed the threshold (Olsson et al., 2002).

There are large regional differences in the observed dioxin concentrations in Baltic herring (Olsson et al., 2002; Kiviranta et al., 2003; Roots et al., 2003; Shelepchikov et al., 2003; Roots \& Zitko, 2004) and sprat (Kiviranta et al., 2003; Roots et al., 2003; Shelepchikov et al., 2003). The aim of the investigations in different parts of the Baltic Sea was to pinpoint the regions with higher toxicant concentrations in order to focus on their examination.

The correlation between the dioxin concentration and the age of herring (length, weight) both in spring and autumn was found to be statistically significant $-r^{2}$ exceeded 0.8 in all cases (Fig. 2). Our research data (Tables 1 and 2, Fig. 3) as 


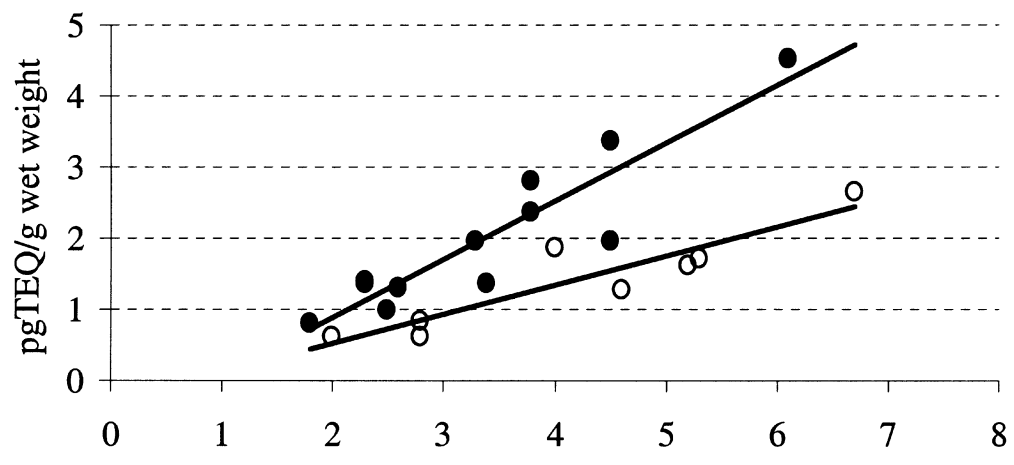

Age, year
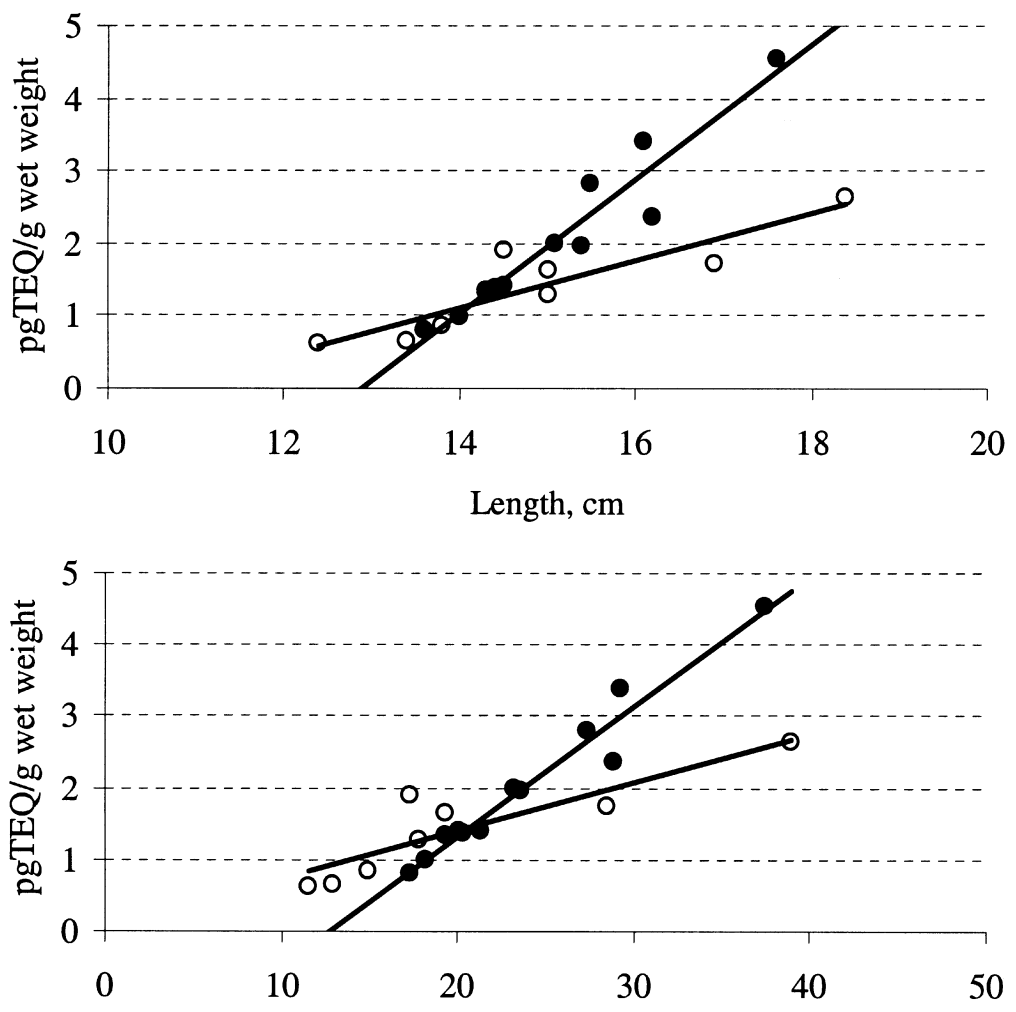

Weight, g

- autumn o spring

Fig. 2. Correlation between dioxin level and age, length, and weight in the Baltic herring tested in spring and autumn 2002 . 
Table 1. PCDD/PCDF concentration in the muscle tissue of Baltic herring in the Estonian coastal waters in spring 2002

\begin{tabular}{c|c|c|c|c|c}
\hline Area & $\begin{array}{c}\text { Length, } \\
\text { cm }\end{array}$ & $\begin{array}{c}\text { Weight, } \\
\mathrm{g}\end{array}$ & $\begin{array}{c}\text { Age, } \\
\text { years }\end{array}$ & $\begin{array}{c}\text { Lipid content, } \\
\%\end{array}$ & $\begin{array}{c}\text { pg TEQ/g } \\
\text { wet weight }\end{array}$ \\
\hline Open Baltic Sea & 13.8 & 14.9 & 2.8 & 1.9 & 0.9 \\
& 18.4 & 38.9 & 6.7 & 2.3 & 2.6 \\
Gulf of Finland, & 15.0 & 19.3 & 5.2 & 1.8 & 1.6 \\
western part & 14.5 & 17.3 & 4.0 & 2.1 & 1.9 \\
Gulf of Finland, & 15.0 & 17.8 & 4.6 & 2.1 & 1.3 \\
central part & 13.4 & 13.0 & 2.8 & 1.9 & 0.6 \\
Gulf of Riga & 16.9 & 28.5 & 5.3 & 2.7 & 1.7 \\
& 12.4 & 11.5 & 2.0 & 2.0 & 0.6
\end{tabular}

Table 2. Concentration of dioxins in the Baltic herring and sprat from Estonian coastal waters in autumn 2002

\begin{tabular}{|c|c|c|c|c|c|}
\hline Area & $\begin{array}{l}\text { Length, } \\
\mathrm{cm}\end{array}$ & $\begin{array}{l}\text { Weight, } \\
\mathrm{g}\end{array}$ & $\begin{array}{l}\text { Age, } \\
\text { years }\end{array}$ & $\begin{array}{c}\text { Lipid content, } \\
\%\end{array}$ & $\begin{array}{l}\mathrm{pg} T E Q / \mathrm{g} \\
\text { wet weight }\end{array}$ \\
\hline \multicolumn{6}{|c|}{ Herring } \\
\hline \multirow[t]{3}{*}{ Open Baltic Sea } & 17.6 & 37.4 & 6.1 & 12.2 & 4.5 \\
\hline & 16.1 & 29.3 & 4.5 & 12.2 & 3.4 \\
\hline & 15.5 & 27.4 & 3.8 & 12.1 & 2.8 \\
\hline \multirow{3}{*}{$\begin{array}{r}\text { Gulf of Finland, } \\
\text { western part }\end{array}$} & 15.1 & 23.3 & 3.3 & 7.6 & 2.0 \\
\hline & 14.0 & 18.2 & 2.5 & 7.1 & 1.0 \\
\hline & 13.6 & 17.3 & 1.8 & 8.1 & 0.8 \\
\hline \multirow{3}{*}{$\begin{array}{c}\text { Gulf of Finland, } \\
\text { central part }\end{array}$} & 15.4 & 23.6 & 4.5 & 6.7 & 2.0 \\
\hline & 14.4 & 20.1 & 3.4 & 8.6 & 1.4 \\
\hline & 14.3 & 19.3 & 2.6 & 8.1 & 1.3 \\
\hline \multirow[t]{3}{*}{ Gulf of Riga } & 16.2 & 28.9 & 3.8 & 10.4 & 2.4 \\
\hline & 14.5 & 21.3 & 2.3 & 10.7 & 1.4 \\
\hline & 14.3 & 20.4 & 2.3 & 10.6 & 1.4 \\
\hline \multicolumn{6}{|c|}{ Sprat } \\
\hline \multirow[t]{2}{*}{ Open Baltic Sea } & 12.0 & 11.2 & 2.5 & 15.1 & 2.4 \\
\hline & 12.0 & 10.9 & 2.7 & 14.6 & 2.6 \\
\hline \multirow{4}{*}{$\begin{array}{r}\text { Gulf of Finland, } \\
\text { western part }\end{array}$} & 12.6 & 12.8 & 3.8 & 11.5 & 2.1 \\
\hline & 12.0 & 11.7 & 2.9 & 12.7 & 2.1 \\
\hline & 12.1 & 11.8 & 3.0 & 12.3 & 2.0 \\
\hline & 11.8 & 11.2 & 2.5 & 13.3 & 1.7 \\
\hline \multirow{2}{*}{$\begin{array}{c}\text { Gulf of Finland, } \\
\text { central part }\end{array}$} & 11.8 & 11.0 & 2.6 & 15.5 & 1.6 \\
\hline & 11.6 & 10.3 & 1.9 & 15.7 & 2.5 \\
\hline
\end{tabular}




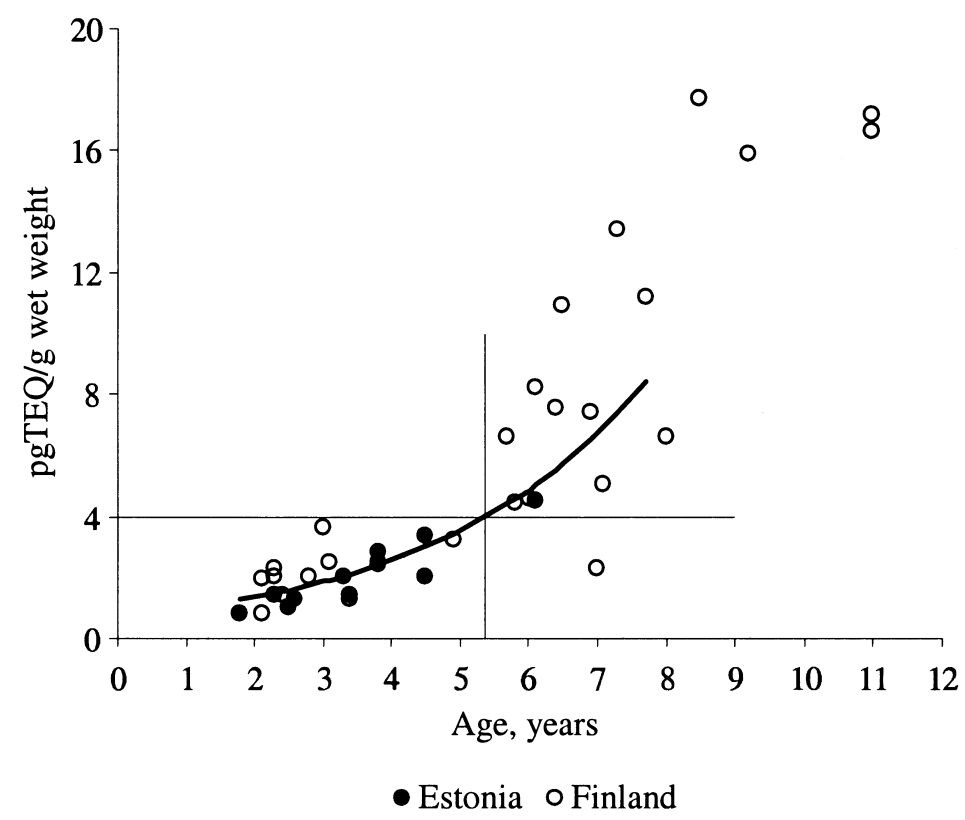

Fig. 3. Dioxin concentration (pgTEQ/g wet weight) in Estonian (Roots et al., 2003) and Finnish (Isosaari et al., 2003; Kiviranta et al., 2003) Baltic Sea herring muscle tissue.

well as the results of Finnish researchers of dioxin concentrations in Baltic herring in the northern part of the Baltic Sea (Kiviranta et al., 2003) reveal a distinct correlation between the age of fish and dioxin levels (Roots et al., 2003; Roots \& Zitko, 2004).

Of the 12 Baltic herring samples taken from regions in Estonian coastal waters and the open Baltic Sea only one (fish older than 6 years and more than $17 \mathrm{~cm}$ in length) showed a dioxin concentration above the internationally permitted threshold (Table 2).

However, the Russian data show a rather high level of PCDD/PCDF pollution in the Baltic seafood. Highest concentrations analysed in Baltic herring amounted to $11.46 \mathrm{pg}$ TEQ/g fresh weight (Shelepchikov et al., 2003). Thus, the results do not exclude the need to monitor toxicants in fish also in the future; moreover, the use of hazardous chemicals in the Baltic Sea region will probably continue.

\section{CONCLUSIONS}

In eight Baltic herring samples taken from three regions of Estonian coastal waters and the open Baltic Sea during the spring of 2002 and in eight sprat samples taken from two regions of Estonian coastal waters and the open Baltic Sea during 
the autumn of 2002 the dioxin concentrations were all below the internationally permitted threshold (Council Regulation (EC) No. 2375/2001 of November 2001). Therefore, according to the international normatives the Baltic herring caught from the Estonian coastal waters was qualified for eating.

Of the twelve Baltic herring samples taken from regions of Estonian coastal waters and the open Baltic Sea only one (fish older than 6 years and more than $17 \mathrm{~cm}$ in length, caught from the open Baltic Sea) had higher dioxin concentration than the internationally permitted threshold.

\section{ACKNOWLEDGEMENTS}

The project was financially supported by the Estonian Ministries of Agriculture and Environment.

\section{REFERENCES}

Isosaari, P., Kiviranta, H., Hallikainen, A., Parmanne, R., Vuorinen, P. J. \& Vartiainen, T. 2003. Dioxin levels in fish caught from the Baltic Sea in 2001-2002. Organohalogen Compd., 62, $41-44$.

Kiviranta, H., Vartiainen, T., Parmanne, R., Hallikainen, A \& Koistinen, J. 2003. PCDD/Fs and PCBs in Baltic herring during the 1990s. Chemosphere, 50, 1201-1216.

Koistinen, J., Nuuja, I., Koivusaari, J. \& Paasivirta, J. 1995. PCDEs, PCBs, PCDDs and PCDFs in black guillermots and white-tailed sea eagles from the Baltic Sea. Chemosphere, 30, 16711684 .

Olsson, M., Bignert, A., Aune, M., Haarich, M., Harms, U., Korhonen, M., Poutanen, E., Roots, O. \& Sapota, G. 2002. Organic contaminants. In Environment of the Baltic Sea Area 19941998. Baltic Sea Env. Proc., No. 82B, HELCOM, 133-140.

Raid, T. 1996. Main commercial sea fish stocks. In Estonian Environment: Past, Present and Future (Raukas, A., ed.), pp. 78-82. Ministry of the Environment of Estonia, Tallinn.

Roots, O. 1996. Toxic Chlororganic Compounds in the Ecosystem of the Baltic Sea. Estonian Environment Information Centre, Tallinn.

Roots, O. \& Aps, R. 1993. Polychlorinated biphenyls and organochlorine pesticides in Baltic herring and sprat. Toxicol. Envir. Chem., 37(3-4), 195-205.

Roots, O. \& Zitko, V. 2004. Chlorinated dibenzo-p-dioxins and dibenzofurans in the Baltic herring and sprat of Estonian coastal waters. Envir. Sci. Pollut. Res., 3, 186-193.

Roots, O., Lahne, R., Simm, M. \& Schramm, K.-W. 2003. Dioxins in the Baltic herring and sprat in Estonian coastal waters. Organohalogen Compd., 62, 201-203.

Rylander, L., Strömberg, U. \& Hagmar, L. 1995. Decreased birth weight among infants born to women with a high dietary intake of fish contaminated with persistent organochlorine compounds. Scand. J. Work Environ. Health, 21, 368-375.

Shelepchikov, A., Klyev, N., Shenderyuk, V., Baholdina, L. \& Brodsky, E. 2003. Contamination of Russian Baltic fish by PCDD/F. Organohalogen Compd., 62, 1-4.

UNEP Chemicals. 1999. Dioxin and Furan Inventories. National and Regional Emissions of $P C D D / P C D F$. Geneva. 


\title{
Läänemere kirdeosa räime ja kilu polükloreeritud dioksiini- ja furaanisisaldus
}

\author{
Ott Roots, Karl-Werner Schramm, Mart Simm, Bernhard Henkelmann \\ ja Ain Lankov
}

2002. aasta kevadel ja sügisel määrati esmakordselt Eesti kalade polükloreeritud dioksiini- ja furaanisisaldus. Tegemist on väga toksiliste, püsivate ja vähkitekitavate ühenditega, mida keemiatööstuses ei toodeta, vaid need tekivad tootmise kahjulike kõrvalproduktidena. Kuna Eestis puudub siiani eeltoodud toksikantide analüüsi võimalus, telliti analüüsid Saksamaalt Keemilise Ökoloogia Instituudist, mis on akrediteeritud kalade dioksiinianalüüside läbiviimiseks (akrediteerimislitsents nr DAC-P-0141-01-00, kehtiv kuni 21.11.2006).

2002. aasta kevadel ja sügisel Eesti rannikumerest püütud räimede ja kilude dioksiini- ja furaanisisaldus oli allapoole Euroopas kehtivaid norme. Räime puhul uuriti dioksiini- ja furaanisisalduse sõltuvust kalade vanusest, pikkusest ja kaalust. Saadud tulemusi võrreldi Soome teadlaste vastavate tulemustega.

Kolmest räimeproovist, mis olid võetud Läänemere avaosast, oli ainult ühes proovis (räimed olid vanemad kui 6 aastat ja pikemad kui $17 \mathrm{~cm}$ ) dioksiini- ja furaanisisaldus üle Euroopa normi. 